\title{
Subcellular Responses in Nonhost Plant Infected with Pathogenic and Non- pathogenic Strains of Xanthomonas axonopodis pv. glycines
}

\author{
Yong Ho Jeon, Jung-Gun Kim ${ }^{1}$, Sung-Pae Chang, Ingyu Hwang ${ }^{1}$ and Young Ho Kim* \\ School of Agricultural Biotechnology and Center for Plant Molecular Genetics \& Breeding Research, Suwon 441-744, Korea \\ ${ }^{I}$ School of Agricultural Biotechnology, Seoul National University, Suwon 441-744, Korea
}

(Received on March 26, 2002)

Xanthomonas axonopodis pv. glycines, the causal agent of bacterial pustule of soybean, induces hypersensitive response (HR) in a non-host plant, hot pepper (Capsicum annuum). A wild-type strain (8ra) and its non-pathogenic mutant (8-13) of $X$. axonopodis pv. glycines were inoculated into the pepper leaf tissues and their subcellular responses to the bacterial infections were examined by electron microscopy. Ultrastructural changes related to HR were found in the leaf tissues infected with 8 ra from 8 h after inoculation, characterized by separation of plasmalemma from the cell wall, formation of small vacuoles and vesicles, formation of cell wall apposition, and cellular necrosis. No such responses were observed in the tissues infected with the mutant. In 8ra, the bacterial cells were attached to the cell walls, with the cell wall material dissolved into and appearing to encapsulate the bacterial cells. The bacterial cells later became entirely embedded in the cell wall material. On the other hand, in 8-13, the bacterial cells were usually not attached tightly to the plant cell wall, and no or poor encapsulation of the bacteria by the wall material occurred, although these were encircled by rather loose wall materials at the later stages.

Keywords : cell death, electron microscopy, hot pepper, hypersensitive response, Xanthomonas axonopodis pv. glycines.

Xanthomonas axonopodis pv. glycines (formerly $X$. campestris pv. glycines) is the causal agent of bacterial pustule of soybean, and has been reported in most countries where soybean is grown. It occurs severely in soybean fields, when warm temperatures and frequent rains prevail during the growing season, and causes premature leaf defoliation resulting in reduction of seed production (Hwang and Lim, 1992). In susceptible plants, spots of minute specks to large, irregular, mottled brown areas are formed on leaves with or without pustules, and the leaves become ragged and defoliate later.

\footnotetext{
*Corresponding author.

Phone) +82-31-290-2444, FAX) +82-31-294-5881

E-mail)yhokim@snu.ac.kr
}

Various factors have been identified in relation to pathogenicity of the bacterium. However, single hormonal or enzymatic factors do not totally govern the pathogenicity (Fett and Dunn, 1987; Hwang et al., 1992). Lindgren et al. (1986) found that genes responsible for pathogenicity and hypersensitive response (HR) in non-host plants in a Gramnegative bacterium Pseudomonas syringae pv. phaseolicola are known as hrp (hypersensitive response and pathogenicity) genes. Major phenotypes of $h r p$ mutants that have lost pathogenicity also involve the inability of causing HR in non-host plants. The loss of pathogenicity ofhrp mutants is associated with reduced multiplication of $X$. axonopodis pv. glycines in host tissues (Hwang et al., 1992).

For $X$. axonopodis pv. glycines, HR was lost or reduced in non-host plants inoculated with transposon mutants of $X$. axonopodis pv. glycines 8ra (a wild-type strain) (Park and Hwang, 1999). Identified hrp genes from this bacterium were different from other Gram-negative bacteria. All other known hrp mutants of other plant-pathogenic bacteria are non-pathogenic and unable to cause HR (Hueck, 1998). However, some hrp mutants of $X$. axonopodis pv. glycines lose the ability to cause HR (Han et al., 2001). The above aspects suggest that in $X$. axonopodis pv. glycines, genes for governing pathogenicity in host plant may be different from those for HR in non-host plant.

The pathogenicity loss of $X$. axonopodis pv. glycines by transposon mutation of $h r p$ genes was related to the inability of multiplication in vivo (Park and Hwang, 1999). However, it is unlikely that the loss of HR in non-host plants was due to bacterial multiplication because both pathogenic and non-pathogenic bacterial strains do not induce bacterial diseases in non-host plants. There may be differences in the host-parasite relations that can discriminate between $\mathrm{HR}$ and non-HR in non-host plants. Therefore, this study aimed to examine differential subcellular responses in pepper, a non-host plant, infected with pathogenic and non-pathogenic strains of $X$. axonopodis pv. glycines.

\section{Materials and Methods}

Bacterial strains and plant. The bacterial strains used in this 
study were $X$. axonopodis pv. glycines wild-type strain 8ra and its transposon mutant $8-13$, which is non-pathogenic (Park and Hwang, 1999). The bacterial strains were grown on yeast extract calcium carbonate (YDC) agar (Schaad, 1988) at $28^{\circ} \mathrm{C}$ for 3 days before use.

Inoculation. Pepper (Capsicum annuum L. cv. Dabokkun) plants were grown at $25^{\circ} \mathrm{C}$ in a greenhouse. Bacterial cells on the agar medium were suspended in sterilized distilled water and adjusted to $2-5 \times 10^{8}$ cells $/ \mathrm{ml}$, and injected into fully expanded leaves of whole plants. The inoculated plants were placed at $25^{\circ} \mathrm{C}$ in the greenhouse.

Electron microscopy. Leaf tissues injected with the bacterial cells were excised and fixed in Karnovsky's fixative in $0.05 \mathrm{M}$ cacodylate buffer ( $\mathrm{pH}$ 7.2) for $2 \mathrm{~h}$ at $4,8,12$, and $18 \mathrm{~h}$ after inoculation. The fixed leaf tissues were rinsed in the same buffer solution three times each for 20 minutes, and post-fixed in $1 \%$ osmium tetroxide for $2 \mathrm{~h}$. The fixed samples were washed briefly in distilled water and stained en bloc with $0.5 \%$ uranyl acetate overnight. These were then dehydrated in an ethanol series $(30 \%$, $50 \%, 80 \%, 95 \%$, and $100 \%$ ), and embedded in Spurr's epoxy resin (Spurr, 1969). Ultrathin sections of $80-90 \mathrm{~nm}$ in thickness were made with a diamond knife. The sections were stained with uranyl acetate and lead citrate, and observed under a JEM-1010 electron microscope (JEOL, Japan) at $80 \mathrm{kV}$.

\section{Results}

Pepper leaves injected with the bacterial suspension of $X$. axonopodis pv. glycines 8ra had no symptom of hypersensitive response at less than $12 \mathrm{~h}$ after inoculation. However, water-soaking area was formed around the inoculation site after $12 \mathrm{~h}$, and HR was noted $16-20 \mathrm{~h}$ after inoculation, which was characterized by shiny appearance on the water-soaked area. No such HR was formed by the mutant non-pathogenic bacterial strain 8-13. In the leaf tissue areas inoculated with both bacterial strains, no significant bacterial population changes occurred at $30 \mathrm{~h}$ after inoculation, regardless of pathogenic and non-pathogenic strains (unpublished data).

At $4 \mathrm{~h}$ after inoculation, no structural changes related to programmed cell death were noted both in 8ra (Fig. 1) and 8-13 strains (Fig. 2). The cells adjacent to infecting bacteria were intact, containing healthy chloroplasts and mitochondria. Cytoplasm was also intact. In case of $X$. axonopodis pv. glycines 8ra, the bacterial cells were rather tightly attached to the cell walls, from which the cell wall material was dissolved and encapsulate the bacterial cells (Fig. 1A, B). Sometimes bacterial cells were entirely embedded in the cell wall material especially in the diverging area of intercellular space (Fig. 1C). The bacterial cells of mutant strain $8-13$, on the other hand, were usually not attached tightly to the plant cell wall or dispersed in the intercellular space (Fig. 2). As in 8ra, the material was occasionally dissolved from the cell walls (Fig. 2A, B) or

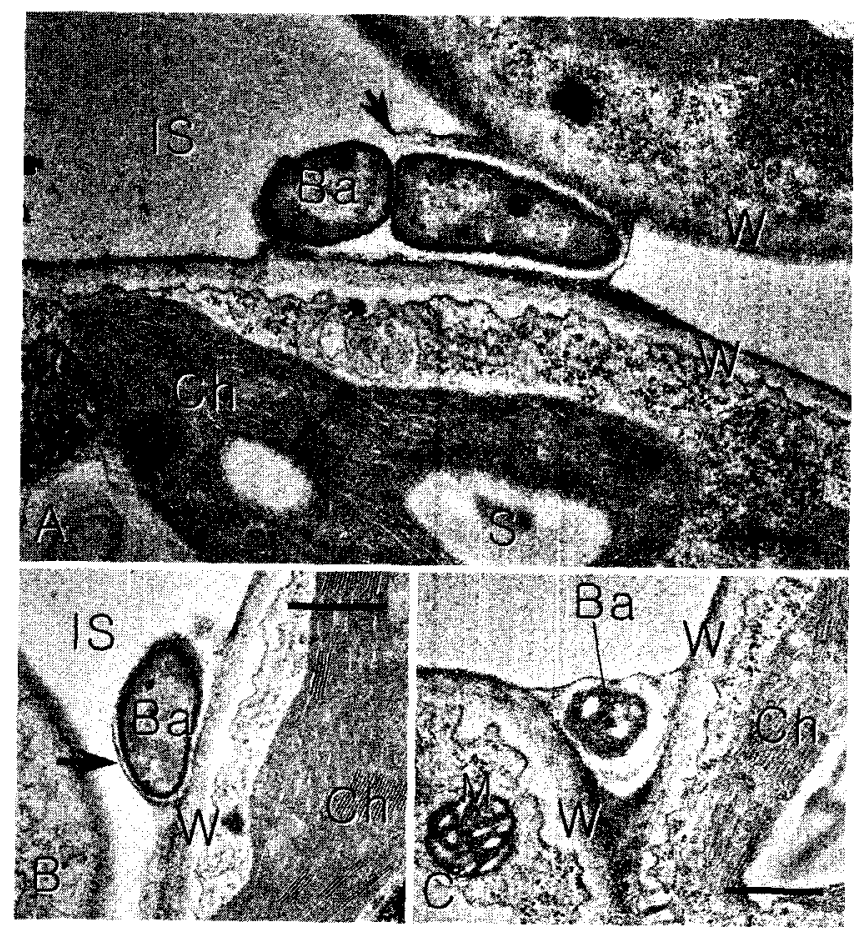

Fig. 1. Pepper leaf tissue infected with Xanthomonas axoropodis pv. glycines $8 \mathrm{ra} 4 \mathrm{~h}$ after inoculation, showing bacterial cells (Ba) attached to plant cell walls (W). Note a material (arrow) probably formed by hydrolysis or enzymolysis encircling the bacterial cells. In (C), the bacterial cell is embedded in the wall material. Cytoplasm adjacent to the bacterial cells is intact, containing intact chloroplast $(\mathrm{Ch})$ and mitochondria (M). IS: intercellular space, $\mathrm{S}$ : starch. Bars $=0.5 \mu \mathrm{m}$.

no material was formed from the cell wall (Fig. 2C, D). However, it did not encircle the bacterial cells. Electrondense materials were deposited around the bacterial cells of 8-13 (Fig. 2A, C, D).

At $8 \mathrm{~h}$ after inoculation, the bacterial cells of $X$. axonopodis pv. glycines 8ra were embedded singly or in group in the encapsulation material, which were firmly attached to the cell wall (Fig. 3). Plant cells affected by the bacterial infection showed a kind of hypersensitive response (HR), characterized by formation of various vesicles (vacuolation) and separation of plasmalemma from the cell wall (Fig. 3A-C). Cytoplasm was granulated and contained numerous vesicles (Fig. 3C). Sometimes vesicles were opened to the space between the cell wall and plasmalemma, and empty or filled vesicles were numerous in the space (Fig. 2C). On the other hand, no such hypersensitive responses were found in leaf cells infected with $X$ axonopodis pv. glycines 8-13 at this time of infection (not photographed).

At $12-18 \mathrm{~h}$ after inoculation with $X$. axonopodis pv. glycines $8 \mathrm{ra}$, the bacterial cells were completely embedded in the cell wall material and prominent cell wall apposition 


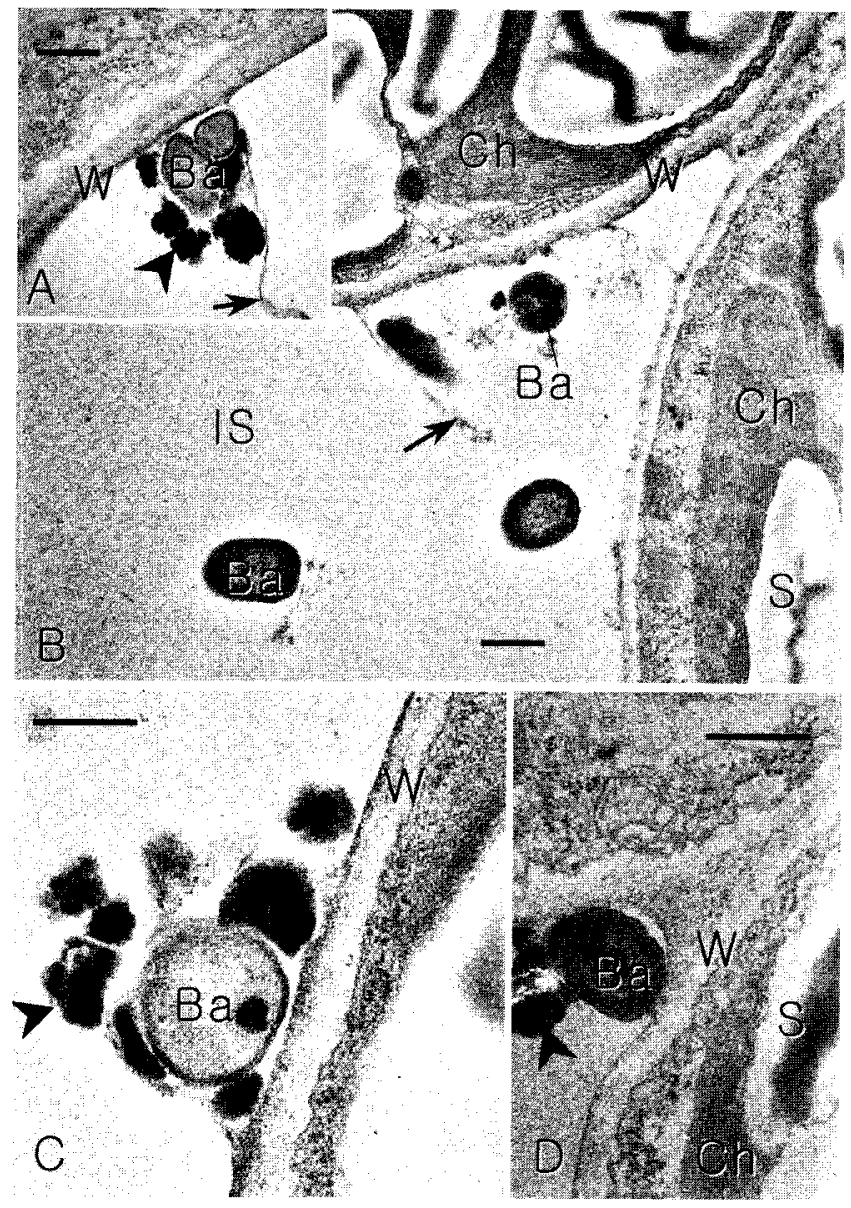

Fig. 2. Pepper leaf tissue infected with Xanthomonas axonopodis pv. glycines 8-13 $4 \mathrm{~h}$ after inoculation, showing bacterial cells (Ba) dispersed in the intercellular space (IS) or attached to the cell wall (W). Note a material (arrow) probably formed by hydrolysis of enzymolysis of cell wall, but does not encircle the bacterial cells. Electron dense materials (arrowhead) accumulated around the bacterial cells (A, C, D). Cytoplasm adjacent to the bacterial cells is intact. Ch: chloroplast, S: starch. Bars $=0.5 \mu \mathrm{m}$.

was formed on the inside cell wall (Fig. 4A, C). Cytoplasm was granulated with small vesicles (Fig. 4B) or necrotized (Fig. 4C). However, leaf tissues inoculated with the nonpathogenic strain 8-13 had no indication of cell wall apposition and cellular necrosis (Fig. 5). The bacterial cells of 8-13 were attached to the cell walls, which were encapsulated loosely by the cell wall material (Fig. 5B). Generally cytoplasm was intact (Fig. 5A), although at a later stage, some HR indications such as cell membrane separation and formation of vesicles were noticed (Fig. 5C, D).

\section{Discussion}

Interactions between plants and plant-pathogenic bacteria
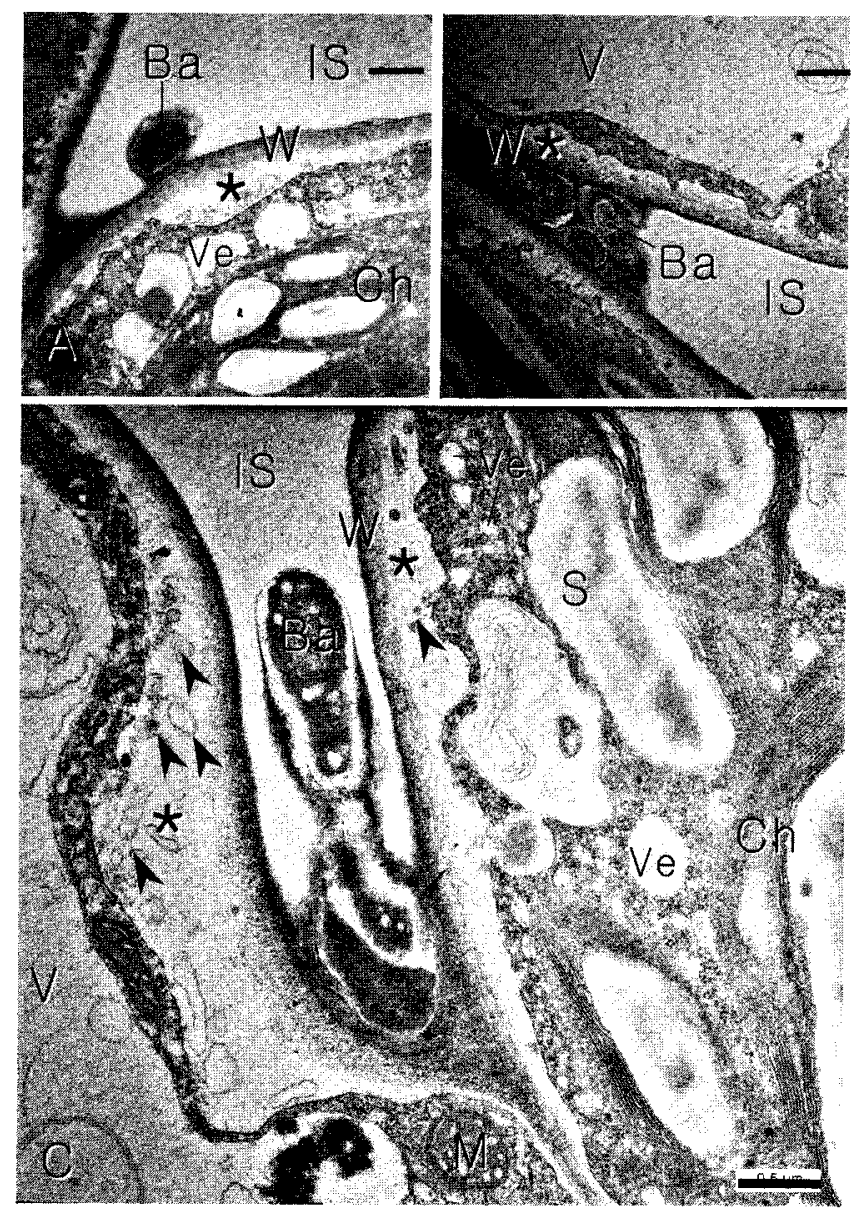

Fig. 3. Pepper leaf tissue infected with Xanthomonas axonopodis pv. glycines $8 \mathrm{ra} 8 \mathrm{~h}$ after inoculation, showing bacterial cells (Ba) cemented to plant cell walls (W). The plant cells show plasmalemma separation (asterisk) from cell wall and formation of numerous vesicles (Ve) in the cytoplasm (vacuolation). Numerous empty or filled vesicles in the space between the cell wall and plasmalemma indicate apposition of wall materials to the primary cell wall. Note that the bacterial cells are embedded in the wall material. Ch: chloroplast, $\mathrm{M}$ : mitochondria, V: vacuole, S: starch. Bars $=0.5 \mu \mathrm{m}$.

are largely divided into susceptible, resistant, and null responses. The $h r p$ gene clusters of plant-pathogenic bacteria are associated with pathogenicity in host plants and resistance in resistant plants in which hypersensitive reaction is elicited. The localized HR in the infection sites of resistant plants are genetically governed by Flor's genefor-gene hypothesis (Flor, 1946; Keen, 1990), which determines resistance by the combination of plant resistance $(R)$ and pathogen avirulence $(a v r)$ genes. Null responses are only phenotypic views, which often occur when hrp gene(s) are mutated to lose pathogenicity. Strain 8-13 has a mutation in a hrp gene homologous to $h r p F$ of $X$. campestris pv. vesicatoria (Park and Hwang, 1999). An hrc $U$-homologous gene mutant of $X$. axonopodis pv. 


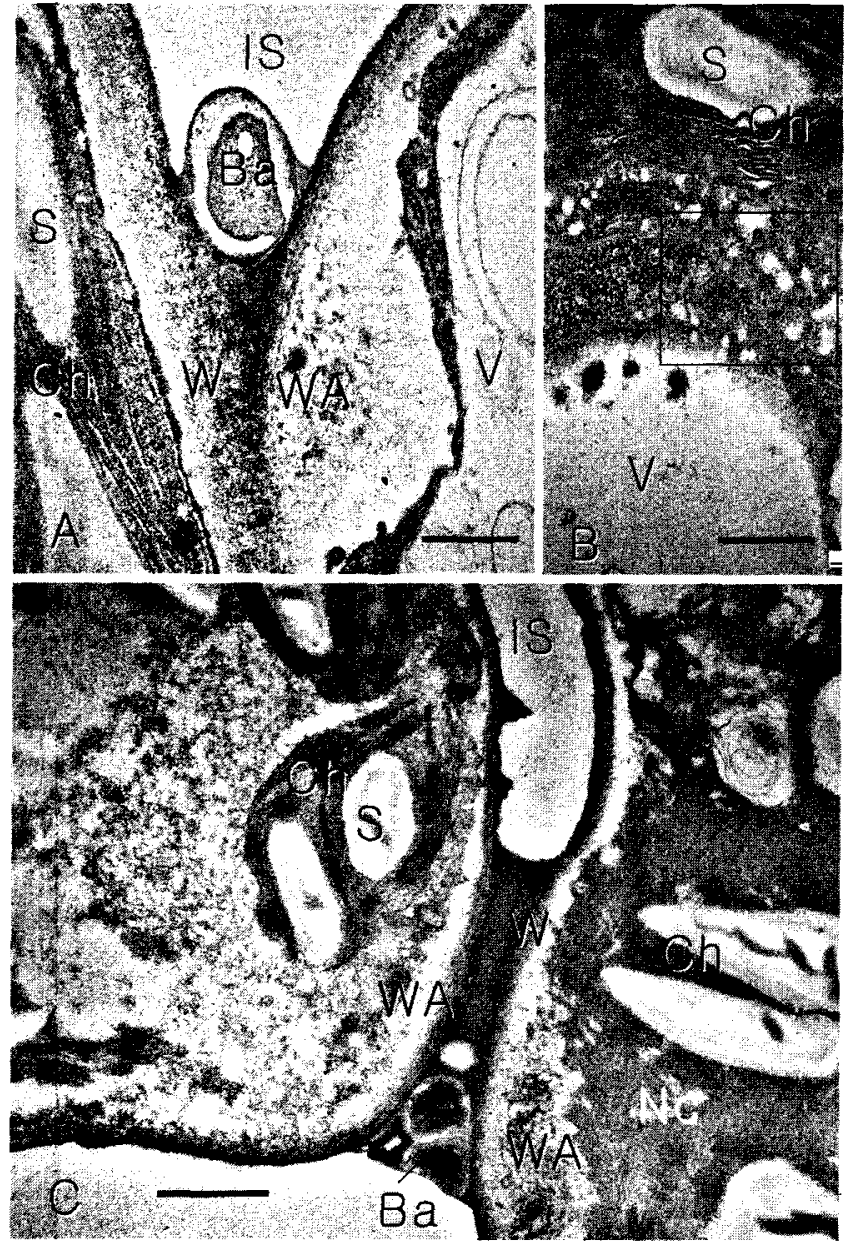

Fig. 4. Pepper leaf tissue infected with Xanthomonas axonopodis pv. glycines 8ra $12 \mathrm{~h}(\mathrm{~A}, \mathrm{~B})$ and $18 \mathrm{~h}(\mathrm{C})$ after inoculation, showing bacterial cells $(\mathrm{Ba})$ embedded in the material from plant cell wall (W). Note prominent cell wall appositions (WA) and necrotic cytoplasm $(\mathrm{Nc})$. The rectangle in (B) shows the formation of various vesicles in granulated cytoplasm. $\mathrm{Ch}$ : chloroplast, M: mitochondria, V: vacuole, S: starch. Bars $=0.5$ $\mu \mathrm{m}$.

glycines which is non-pathogenic can elicit HR on non-host plants (Oh et al., 1999). Mutations in a hrp gene result in delayed plant responses both in susceptible and resistant host plants (Noel et al., 2002).

In this study, HR-type symptoms were observed in the non-host plant (pepper) by the pathogenic strain of $X$. axonopodis pv. glycines after $12 \mathrm{~h}$ of inoculation, but not by the non-pathogenic mutant. Likewise, HR responses in cellular level were only prominent in pepper leaf tissues inoculated with the pathogenic strain. Cellular responses indicating HR in the prenecrotic tissue were noticed $8 \mathrm{~h}$ after inoculation, which were earlier than visual symptom expression. The non-pathogenic strain 8-13 did not cause any significant cellular changes related to HR even at the later stages of infection.
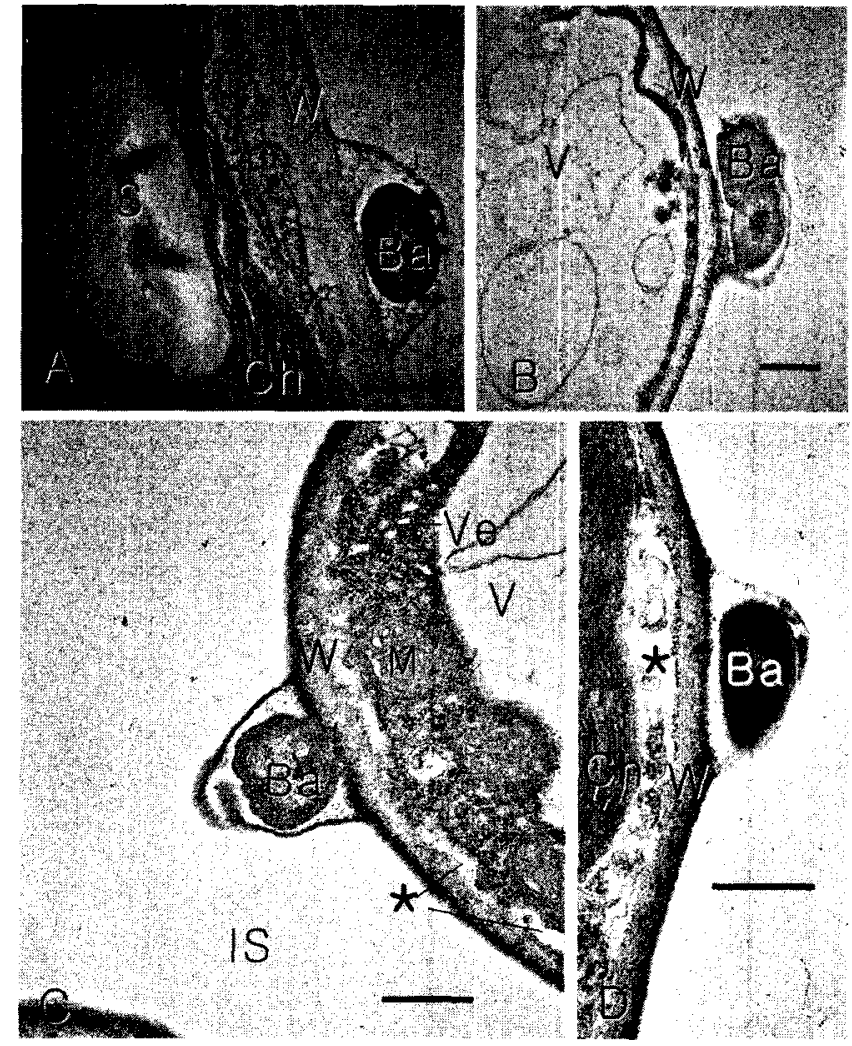

Fig. 5. Pepper leaf tissue infected with Xanthomonas axonopodis pv. glycines 8-13 $12 \mathrm{~h}(\mathrm{~A}, \mathrm{~B})$ and $18 \mathrm{~h}(\mathrm{C})$ after inoculation, showing bacterial cells (Ba) embedded in the loose material from plant cell wall (W). Note that intact cytoplasm in (A), (C) and (D) cellular modifications similar to initial hypersensitive responses, cell membrane separation (asterisk) and formation of vesicles are noted. Ch: chloroplast, $\mathrm{M}$ : mitochondria, V: vacuole, S: starch. $\operatorname{Bars}=0.5 \mu \mathrm{m}$.

Initial cellular reactions associated with $\mathrm{HR}$ involve various processes such as $\mathrm{Ca}^{+}$influx, $\mathrm{K}^{+}$efflux/ $\mathrm{H}^{+}$influx, active oxygen generation, synthesis of phytoalexins and degradative enzymes, deposition of cell wall materials, hallmarks of programmed cell death (PCD), etc. (Dangl and Jones, 2001). $\mathrm{H}_{2} \mathrm{O}_{2}$ accumulates in the cell wall adjacent to infecting bacteria during the oxidative burst in tobacco challenged with Pseudomonas syringae pv. phaseolicola (Mur et al., 2000), in which the transient rise of salicylic acid (SA) has potentiated oxidative burst, resulting in rapid cell death. Ion leakage and membrane disnuption are two measures for cell death.

The initial noticeable structural changes related to the HR in this study were similar to those in soybean cultivars infected with avirulent strains of separation of plasma membrane from the cell wall (plasmolysis) and cytoplasmic vacuolation (Jones and Fett, 1985). In some cells adjacent to the bacteria, dilated endoplasmic reticulum (ER) was prominently formed (not photographed). In the study of 
Mittler et al. (1997), condensation and vacuolization of the cytoplasm and cleavage of nuclear DNA were observed in programmed cell death (PCD). This phenomenon was found in a resistant soybean infected with soybean cyst nematode, showing plasmalemma separation from cell wall in syncytial cells due to nuclear degeneration (Kim et al., 1987). In tobacco, the membrane separation was also found in Tobacco mosaic virus (TMV)-infected cells with PCD (Shin et al., 2001). Plasmolysis is the indication of ion leakage from the cells, which indicates the relative amount of cell death in plant tissues (del Pozo and Lam, 1998). Therefore, these structural features may be characteristic features of initial PCD in pepper leaf tissues infected with $X$. axonopodis pv. glycines.

Cell wall apposition was formed and cytoplasm was necrotized at later stages, which corresponded to the time of the visual HR symptom expression. Cell wall apposition together with necrosis is a common phenomenon in incompatible host parasite interactions (Kim et al., 1987; Riggs et al., 1973; Tu and Hiruki, 1971). Together with membrane separation, wall appositions may wall off the plasmodesmata and prevent cell-to-cell movement of materials, which would lead to a deficit in food supply and build-up of toxic by-products within the cells. Formation of numerous vesicles in the cytoplasm and in the space between the cell wall and plasmalemma at the stage prior to the formation of cell wall apposition may indicate the deposition of cell wall materials to the primary cell wall.

Plant cell walls are a source of signaling molecules that elicit various cell behaviors, such as defense responses to fungal and bacterial pathogen parenchyma cells. In the nonhost plant tissues in this study, some materials from the cell wall encircled the infecting bacteria, which is called immobilization (Jones and Fett, 1985). These cytological responses were only prominent in 8ra. In 8-13, the structures were formed later and were looser than in 8ra. It is known that parenchyma cells produce a fibrillar material that surrounds the bacteria, preventing further multiplication as an induced resistance. The material appeared to result from hydrolysis or enzymolysis of primary cell wall in this study. Jones and Fett (1985) suggested that fibrillar or electron-dense amorphous materials on cell surface are derived from the cell wall. Darvill et al. (1995) also suggested that fragments of polysaccharides from primary cell wall by hydrolysis evoke defense responses in plants and activate mechanisms for resisting potential pathogens. The cell wall modifications may be related to recognition of the pathogen by the plant. Considering that earlier recognition results in faster mobilization of plant defense, plant cells may have recognized the attack of 8ra earlier than 813 , which may be related to the difference in the amount of elicitor(s) between the wild-type and mutant strains (unpublished data).

\section{Acknowledgments}

This work was supported by grant No. R01-2000-00207 from the Basic Research Program of the Korea Science and Engineering Foundation and in part through the Center for Plant Molecular Genetics and Breeding Research. The electron microscope used in this study is JEM-1010 (JEOL, Japan) of the National Instrumenation Center for Environmental Management, Seoul National University.

\section{References}

Dangl, J. L. and Jones, J. D. G. 2001. Plant pathogens and integrated defense responses to infection. Nature 411:826-833.

Darvill, A. G., Albersheim, P., McMeil, M., Lau, J. M., York, W. S., Stevenson, T. T., Thomas, J., Doares, S., Gollin, D. J. and Chelf, P. et al. 1985. Structure and function of plant cell wall polysaccharides. J. Cell Sci. Suppl. 2:203-217.

de Pozo, O. and Lam, E. 1998. Caspases and programmed cell death in the hypersensitive response of plants to pathogens. Curr. Biology 8:1129-1132.

Fett, W. F. and Dunn, M. F. 1987. Auxin production by plantpathogenic pseudomonads and xanthomonads. Appl. Environ. Microbiol. 53:1839-1845.

Flor, H. H. 1946. Genetics of reaction to rust in flax. J. Agric. Res. 73:680-685.

Han, S.-W., Oh, C.-S. and Heu, S.-G. 2001. The characterization of the $h r p$ gene cluster isolated from Xanthomonas axonopodis pv. glycines and X. oryzae pv. oryzae. Plant Pathol. J. 17: 362 (Abstr.).

Hueck, C. J. 1998. Type protein secretion systems in bacterial pathogens of animals and plants. Microbiol. Mol. Biol. Rev. 62:379-433.

Hwang, I. and Lim, S. M. 1992. Use of detached soybean cotyledons for testing pathogenicity of Xanthomonas campestris pv. glycines. Plant Dis. 76:182-183.

Hwang, I., Lim, S. M. and Shaw, P. D. 1992. Cloning and characterization of pathogenicity genes from Xanthomonas campestris pv. glycines. J. Bacteriol. 174:1923-1931.

Jones, S. B. and Fett, W. F. 1985. Fate of Xanthomonas campestris infiltrated into soybean leaves: An ultrastructural study. Phytopathology 75:733-741.

Keen, N. T. 1990. Gene-for-gene complementarity in plant-pathogen interactions. Ann. Rev. Genet. 24:447-463.

Kim, Y. H., Riggs, R. D. and Kim, K. S. 1987. Structural changes associated with resistance of soybean to Heterodera glycines. J. Nematol. 19:177-187.

Lindgren, P. B., Peet, R. C. and Panopoulos, N. J. 1986. Gene cluster of Pseudomonas syringae pv. phaseolicola controls pathogenicity of bean plants and hypersensitive on nonhost plants. J. Bacteriol. 168:512-522.

Mittler, R., Simon, L. and Lam, E. 1997. Pathogen-induced pro- 
grammed cell death in tobacco. J. Cell Sci. 110:1333-1344.

Mur, L. A. J., Brown, I. R., Darby, R. M., Bestwick, C. S., Bi, Y.M., Mansfield, J. W. and Drapper, J. 2000. A loss of resistance to avirulent bacterial pathogens in tobacco is associated with the attenuation of a salicylic acid-potentiated oxidative burst. Plant J. 23:609-621.

Noel, L., Thieme, R., Nennstiel, D. and Bonas, U. 2002. Two novel type -secreted proteins of Xanthomonas campestris pv. vesicatoria are encoded within the $h r p$ pathogenicity island. $J$. Bacteiol. 184:1340-1348.

Oh, C., Heu, S., Yoo, J. Y. and Cho, Y. 1999. An hrcU-homologous gene mutant of Xanthomonas campestris pv. glycines 8ra that lost pathogenicity on the host plant but was able to elicit the hypersensitive response on nonhosts. Mol. Plant Microbe Interact. 12:633-639.

Park, B. K. and Hwang, I. 1999. Identification of $h r c C$, $h r p F$, and miaA genes of Xanthomonas campestris pv. glycines 8ra:
Roles in pathogenicity and inducing hypersensitive response on nonhost plants. Plant Pathol. J. 15:21-27.

Riggs, R. D., Kim, K. S. and Gipson, I. 1973. Ultrastructural changes in Peking soybeans infected with Heterodera glycines. Phytopathology 63:76-84.

Schaad, N. W. 1998. Laboratory guide for identification of plant pathogenic bacteria. 2nd ed. American Phytopathological Society., St Paul, Minn, USA.

Shin, J.-S., Chae, S.-Y. and Kim, Y. H. 2001. Ultrastructural changes during programmed cell death of tobacco leaf tissues infected with Tobacco mosaic virus. Plant pathol. J. 17:315324.

Spurr, A. R. 1969. A low viscosity epoxy resin embedding medium for electron microscopy. J. Ultrastr. Res. 26:31-43.

Tu, J. C. and Hiruki, C. 1971. Electron microscopy of cell wall thickenings in local lesions of potato virus-M infected red kidney bean. Phytopathology 61:862-868. 